University of Nebraska - Lincoln

DigitalCommons@University of Nebraska - Lincoln

Agronomy \& Horticulture -- Faculty Publications

Agronomy and Horticulture Department

2012

\title{
Optimizing Cover Crop Benefits with Diverse Mixtures and an Alternative Termination Method
}

\author{
Samuel E. Wortman \\ University of Nebraska-Lincoln, swortman@unl.edu \\ Charles Francis \\ University of Nebraska-Lincoln, cfrancis2@unl.edu \\ Mark L. Bernards \\ University of Western Illinois \\ Rhae A. Drijber \\ University of Nebraska-Lincoln, rdrijber1@unl.edu \\ John L. Lindquist \\ University of Nebraska-Lincoln, jlindquist1@unl.edu
}

Follow this and additional works at: https://digitalcommons.unl.edu/agronomyfacpub

Part of the Agriculture Commons, and the Plant Sciences Commons

Wortman, Samuel E.; Francis, Charles; Bernards, Mark L.; Drijber, Rhae A.; and Lindquist, John L., "Optimizing Cover Crop Benefits with Diverse Mixtures and an Alternative Termination Method" (2012). Agronomy \& Horticulture -- Faculty Publications. 615.

https://digitalcommons.unl.edu/agronomyfacpub/615

This Article is brought to you for free and open access by the Agronomy and Horticulture Department at DigitalCommons@University of Nebraska - Lincoln. It has been accepted for inclusion in Agronomy \& Horticulture -Faculty Publications by an authorized administrator of DigitalCommons@University of Nebraska - Lincoln. 


\title{
Optimizing Cover Crop Benefits with Diverse Mixtures and an Alternative Termination Method
}

\author{
Sam E. Wortman,* Charles A. Francis, Mark L. Bernards, \\ Rhae A. Drijber, and John L. Lindquist
}

\begin{abstract}
Previous studies have demonstrated benefits of individual cover crop species, but the value of diverse cover crop mixtures has received less attention. The objectives of this research were to determine the effects of spring-sown cover crop mixture diversity and mechanical cover crop termination method on cover crop and/or cash crop productivity, soil moisture and N, and profitability in an organic cropping system. An experiment was conducted between 2009 and 2011 near Mead, NE, where mixtures of two (2CC), four (4CC), six (6CC), and eight (8CC) cover crop species, or a summer annual weed mixture were included in a sunflowersoybean-corn rotation. Cover crops were terminated in late May using a field disk or sweep plow undercutter. Undercutting cover crops increased soil $\mathrm{NO}_{3}-\mathrm{N}(0-20 \mathrm{~cm})$ by 1.0 and $1.8 \mathrm{mg} \mathrm{NO}_{3}-\mathrm{N} \mathrm{kg}^{-1}$ relative to disk incorporation in 2010 and 2011 , respectively. Cover crop mixtures often reduced soil moisture $(0-8 \mathrm{~cm})$ before main crop planting, though cover crop termination with the undercutter increased soil moisture content by as much as $0.024 \mathrm{~cm}^{3} \mathrm{~cm}^{-3}$ compared to termination with the disk during early main crop growth. Crop yields were not influenced by cover crop mixture, but termination with the undercutter increased corn and soybean yield by as much as 1.40 and $0.88 \mathrm{Mg} \mathrm{ha}^{-1}$, respectively. Despite differences in productivity between spring cover crop mixtures and weed communities, crop yield was not different among these treatments; thus, profitability of the weed mixture-undercutter treatment combination was greatest due to reduced input costs.
\end{abstract}

$\mathrm{C}$ OVER CROPS HAVE been shown to provide many environmental and agronomic services within agroecosystems. These include reduced soil erosion, increased biological diversity (e.g., microbes, insects, and birds), increased nutrient cycling and biological $\mathrm{N}_{2}$ fixation, increased soil organic matter, improved weed control, and increased crop yield (Pimentel et al., 1992; Pimentel et al., 1995; Sainju and Singh, 1997; Williams et al., 1998; Altieri, 1999; Reddy et al., 2003; Teasdale et al., 2007). While cover crops have traditionally been used as a soil conservation tool (Pimentel et al., 1995), there is increasing interest in using cover crops to enhance agronomic crop performance. However, maximizing agronomic benefits associated with cover crops will depend on appropriate species choice and residue management (Ashford and Reeves, 2003; Wortman et al., 2012). Selecting a single species is often popular among farmers due to the ease of planting, uniform development, and predictable termination efficacy of the cover crop (Creamer et al., 1995; Mirsky et al., 2009). However, multi-species mixtures may increase productivity, stability, resilience, and resource-use efficiency of the cover crop community (Tilman, 1996; Tilman et al., 1997, 2001; Trenbath, 1999; Wortman et al., 2012).

S.E. Wortman, C.A. Francis, R.A. Drijber, and J.L. Lindquist, Dep. of Agronomy and Horticulture, Univ. of Nebraska- Lincoln, Lincoln, NE 68583; M.L. Bernards, School of Agriculture, Univ. of Western Illinois, Macomb, IL 61455. Received 23 May 2012. *Corresponding author (sam. wortman@huskers.unl.edu).

Published in Agron. J. 104:1425-1435 (2012)

Posted online 1 Aug. 2012

doi:10.2134/agronj2012.0185

Copyright (c) 2012 by the American Society of Agronomy, 5585 Guilford Road, Madison, WI 53711. All rights reserved. No part of this periodical may be reproduced or transmitted in any form or by any means, electronic or mechanical, including photocopying, recording, or any information storage and retrieval system, without permission in writing from the publisher.
Despite the demonstrated benefits, on-farm adoption remains limited due to farmer concerns about the potential cost and management implications of cover crop use. One of the top concerns among farmers is the amount of soil water used by cover crops, potentially reducing available soil moisture for the cash crop. During seasons with average and above-average rainfall conditions, differences in available soil moisture among cover crop species and mixtures are often undetectable. However, when cover crop productivity is high and precipitation becomes limiting, species can differ greatly in their effects on soil moisture (Unger and Vigil, 1998; Daniel et al., 1999). While transpiration demands will undoubtedly vary among species, the method of cover crop termination and residue management may have a greater impact on available soil moisture during main crop growth. Daniel et al. (1999) found that volumetric soil moisture (\%) was increased by as much as $2.4 \%$ to a depth of $61 \mathrm{~cm}$ when cover crops were terminated with herbicides in a no-till system compared to conventional termination with a field disk. Soil water savings associated with no-till practices have been well documented (Blevins et al., 1983; De Vita et al., 2007), but the additional benefits of cover crop residue in a conservation tillage system are not as clear. Liebl et al. (1992) found that transpiration reduced available soil moisture during dry periods, but following no-till termination cover crop residue conserved soil moisture relative to a no-till system without cover crops. Given that the driest portion of the growing season in the western Corn Belt typically occurs after cover crop growth (i.e., June-August), potential soil moisture savings offered by the residue (post-termination) throughout the growing season may negate moisture deficits observed during cover crop growth.

Abbreviations: CC, cover crop mixture; DAT, days after termination; DOY, day of year; NC, weed-free and cover crop-free control; WD, weedy mixture and cover crop-free. 
Despite concerns about water use, many farmers are interested in cover crops because of the potential for improved nutrient cycling and biological $\mathrm{N}_{2}$ fixation. As a result, species in the Fabaceae (legume) family are among the most popular and expensive cover crops. Legumes (e.g., green manures) have been shown to reduce synthetic $\mathrm{N}$ input demands by 50 to $100 \%$ depending on species, the duration of cover crop growth, and subsequent crop $\mathrm{N}$ requirement (Biederbeck et al., 1996; Burket et al., 1997). While legume species have the potential to biologically fix $\mathrm{N}$, faster growing cover crop species (e.g., grass and mustard spp.) may be more useful in scavenging nitrates and nutrient cycling (Dabney et al., 2001). A mixture of legume and nonlegume species may maximize the benefits of biological $\mathrm{N}_{2}$ fixation and nutrient cycling, as legumes can increase $\mathrm{N}$ availability to other species in mixture leading to increased productivity (Kuo and Sainju, 1998; Mulder et al., 2002). In addition, termination method and residue management can influence $\mathrm{N}$ mineralization, soil availability, and crop uptake (Sainju and Singh, 2001). Incorporation of cover crop residue via field disk or plow often results in rapid $\mathrm{N}$ mineralization and plant availability, but management of residue on the soil surface has been shown to result in greater crop N uptake and yield (Sainju and Singh, 2001). Therefore, residue management on the soil surface with conservation tillage methods may be effective in syncing $\mathrm{N}$ mineralization and availability with crop demand and uptake (Parr et al., 2011).

Overall, the agronomic objective for cover crop management is to minimize soil water loss and increase the quantity and availability of soil $\mathrm{N}$ to promote increases in crop yield. However, improper management of cover crops can lead to substantial yield loss. The timing and method of cover crop termination have both been shown to affect yield influencing factors including: soil moisture availability, weed communities, cover crop and soil N content, and crop N uptake (Daniel et al., 1999; Mirsky et al., 2009; Parr et al., 2011; Wortman, 2012). Yield loss associated with cover crop use is typically attributed to incomplete cover crop termination, soil moisture deficit, or nutrient immobilization and deficiency (Wagger, 1989; Unger and Vigil, 1998; Mischler et al., 2010); thus, management of cover crop residue should be focused toward termination efficacy, moisture conservation, and optimum soil $\mathrm{N}$ availability during peak crop growth. To this end, conservation tillage implements like the sweep plow undercutter may have great potential (Creamer et al., 1995). In contrast to conventional tillage systems, the undercutter leaves intact residue on the soil surface, minimizes soil inversion, and presumably reduces evaporative loss from the soil. Moreover, the undercutter may be an improvement on conservation implements like the roller-crimper, which is often inconsistent in termination efficacy (Mischler et al., 2010). Despite these production challenges, many cover crop systems have been shown to maintain or increase crop yield (e.g., Clark et al., 1994; Davis, 2010; Mischler et al., 2010). Demonstrating predictable yield and economic benefits associated with cover crop use will be necessary in increasing on-farm adoption.

The objectives of this research were to determine the effects of spring-sown cover crop mixture diversity and mechanical cover crop termination method on cover crop and/or cash crop productivity, soil moisture, soil N, and cropping system profitability. We hypothesized that increasing cover crop diversity will increase total cover crop biomass, and subsequent grain yield, while soil moisture content will not differ among mixtures despite differences in productivity. With regard to cover crop termination, we hypothesized that terminating cover crops with the sweep plow undercutter will increase soil moisture content, soil $\mathrm{N}$ availability, crop yield, and profitability compared to termination with a field disk.

\section{MATERIALS AND METHODS}

\section{Experimental Site and Design}

A field experiment was conducted in 2009,2010, and 2011 at the University of Nebraska-Lincoln Agricultural Research and Development Center (ARDC) near Mead, NE. Dominant soil type at the site is a Sharpsburg silty clay loam (fine, smectitic, mesic Typic Argiudoll) with 0 to 5\% slopes. The experiment was conducted in a 2.8-ha field that is certified for organic production (OCIA International, Lincoln, NE), and is managed without irrigation. This field was in organic alfalfa (Medicago sativa L.) hay production between 2004 and 2008. In the fall of 2008 the experimental area was amended with $50 \mathrm{Mg} \mathrm{ha}^{-1}$ of liquid beef (Bos taurus) feedlot manure (approximately 1.2\% total N content) and incorporated via field disk. In the spring of 2009 , the entire field (excluding a no cover control treatment) was seeded with $8.1 \mathrm{~kg} \mathrm{ha}^{-1}$ of velvetleaf (Abutilon theophrasti) seed, $2.6 \mathrm{~kg} \mathrm{ha}^{-1}$ of common lambsquarters (Chenopodium album) seed, $1.2 \mathrm{~kg} \mathrm{ha}^{-1}$ of redroot pigweed (Amaranthus retroflexus) seed, and $3.7 \mathrm{~kg} \mathrm{ha}^{-1}$ of green foxtail (Setaria viridis) seed to establish a common weed seedbank throughout the field for a concurrent weed management study.

The experiment was designed as a split-plot randomized complete block design within a 3-yr crop rotation with four replications. The rotation sequence consisted of confectionery sunflower (Helianthus annuus L. 'Seeds 2000 Jaguar')-soybean (Glycine max L. Merr. 'Blue River Hybrids 2A71') - corn (Zea mays L. var. 'Blue River Hybrids 57H36'). Within each crop species, whole-plots (9.1 by $21.3 \mathrm{~m} ; 12$ crop rows spaced $0.76 \mathrm{~m}$ apart) were defined by cover

Table I. Cover crop species and seeding rates used in individual cover crop mixtures for 2009 and 20I0-20II (2CC = two species mixture; $4 C C=$ four species mixture; $6 C C=$ six species mixture; $8 C C$ = eight species mixture).

\begin{tabular}{|c|c|c|c|c|c|}
\hline \multirow[b]{2}{*}{ Common name } & \multirow[b]{2}{*}{ Scientific name } & \multicolumn{4}{|c|}{ Cover crop seeding rate } \\
\hline & & $2 C C$ & $4 C C$ & $6 C C$ & $8 \mathrm{CC}$ \\
\hline & & 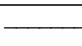 &  & & \\
\hline Hairy vetch & Vicia villosa Roth & 22.4 & 11.2 & 7.5 & 5.6 \\
\hline Buckwheat (2009) & Fagopyrum sagittatum Moench & 28.0 & 14.0 & 9.3 & 7.0 \\
\hline Idagold mustard (20I0-20II) & Sinapis alba L. & 6.7 & 3.4 & 2.2 & 1.7 \\
\hline Field pea & Pisum sativum $\mathrm{L}$. & & 28.0 & 18.7 & 14.0 \\
\hline Pacific Gold mustard & Brassica juncea (L.) Czern. & & 2.2 & 1.7 & I.I \\
\hline Oilseed radish & Raphanus sativus L. & & & 2.8 & 2.1 \\
\hline Crimson clover & Trifolium incarnatum L. & & & 4.7 & 3.5 \\
\hline Dwarf essex rape & Brassica napus L. & & & & 1.7 \\
\hline Chickling vetch & Lathyrus sativus L. & & & & 8.4 \\
\hline
\end{tabular}


crop mixture, while split-plots $(4.6 \times 21.3 \mathrm{~m}$; 6 crop rows spaced $0.76 \mathrm{~m}$ apart) were defined by cover crop termination method. Each "crop $\times$ cover crop mixture $\times$ termination method" treatment combination was replicated within each block so that each phase of the 3-yr crop sequence was present each year within each block. There were six whole-plot cover crop treatments: (i) two-species cover crop mixture (2CC), (ii) four-species cover crop mixture (4CC), (iii) six-species cover crop mixture (6CC), (iv) eight-species cover crop mixture (8CC), (v) weedy mixture and cover crop-free (before main crop planting) (WD), and (vi) weed-free and cover crop-free (before main crop planting) control (NC). The NC whole-plots were field disked and hand-hoed twice before main crop planting, while the WD whole-plots were left unmanaged until cover crop termination. The goal for the WD treatment was to manage existing weed populations as a cover crop. Details on the individual species and seeding rates included in each cover crop mixture whole-plot are included in Table 1.

Split-plot cover crop termination methods included either disking or undercutting. Termination method was randomized within the first replication (southernmost) and duplicated in the remaining three replications (north of the first replication) to facilitate adequate speed for effective tillage operations driving north-south through the field. Disking was conducted with a $4.6 \mathrm{~m}$ wide Sunflower 3300 (Sunflower Mfg., Beloit, KS) disk to an approximate depth of $15 \mathrm{~cm}$. Undercutting was conducted with either a Buffalo 6000 (Buffalo Equipment, Columbus, NE) cultivator (modified for undercutting) with seven overlapping $0.75 \mathrm{~m}$ wide sweep blades (2009) or a Miller Flex-Blade sweep plow undercutter (2010 and 2011) with three overlapping $1.5 \mathrm{~m}$ sweep blades. The undercutter sweeps are designed to cut a level plane through the soil at an approximate depth of $10 \mathrm{~cm}$, severing plant roots and minimizing soil inversion, resulting in a layer of intact surface residue. Details on the design of the undercutter can be found in Creamer et al. (1995).

Table 2. Timing of field operations and data collection for each year of the study.

\begin{tabular}{lccc}
\hline \multirow{2}{*}{ Operation } & \multicolumn{3}{c}{ Year } \\
\cline { 2 - 4 } \multicolumn{1}{c}{ Co09 } & 20 I0 & 20II \\
\hline Cover crop planting & 20 March & 30 March & 2I March \\
Cover crop sampling & $19-2$ I May & 24 May & I June \\
Cover crop termination & 22 May & 28 May & 3 June \\
Main crop planting & 28 May & I-3 June & 6 June \\
First interrow cultivation & I July & 28 June & 30 June \\
Second interrow cultivation & & I July & 8 July \\
First soil sampling & 6-7 July & 29-30 June & 28 June \\
Second soil sampling & II-12 August & 26-27 July & 27-28 July \\
\hline
\end{tabular}

Cover crop mixtures were planted via hand-crank broadcast seeding followed by light incorporation with a John Deere 950 cultipacker (Deere and Company, Moline, IL). Generally, cover crops were planted in late March, terminated in late May, and the main crop was planted within $1 \mathrm{wk}$ of termination. Specific dates for field operations across all years are detailed in Table 2. While fallsown cover crops (e.g., hairy vetch [Vicia villosa Roth] and winter rye [Secale cereale L.]) are more commonly used in the U.S. Corn Belt, there is increasing interest among farmers in spring-sown species. Much of this interest has stemmed from integrated crop- livestock farmers who often struggle to establish fall-sown cover crops in fields where crop residue is grazed in the winter months. Moreover, many farmers cite difficulties in establishing fall-sown cover crop species (e.g., timing and winterkill) as major obstacles to cover crop adoption. Thus, spring-sown species may increase the flexibility of cover crop use in cropping systems leading to greater on-farm adoption.

Seeding rates for confectionery sunflower (Helianthus annuus L.), soybean, and corn (Zea mays L.) were 62,000, 556,000, and 86,000 seeds ha $^{-1}$, respectively. All crops were inter-row cultivated approximately 1 mo after planting the cash crop each season. In 2010 and 2011, all crops were cultivated a second time within $10 \mathrm{~d}$ of the first cultivation in an effort to improve intra-row weed control. Surface residues in the undercutter split-plot experimental units were sufficiently dried and decomposed (due to low $\mathrm{C} / \mathrm{N}$ ratio of the cover crop residues) by this point in the growing season and did not interfere with the cultivation. Seeds of all legume cover crop and crop species were inoculated with appropriate rhizobia bacterial species before planting in 2009 and 2010.

\section{Data Collection}

Monthly precipitation $(\mathrm{mm})$ and temperature $\left({ }^{\circ} \mathrm{C}\right)$ for April to September was determined for each growing season by summing daily precipitation and temperature measurements from the High Plains Regional Climate Center station located on the University of Nebraska Turf Farm near Mead, NE (4110'12" N, 96 28'12" W, elevation $=366 \mathrm{~m})$, located $1 \mathrm{~km}$ northwest of the experimental site (Table 3). Climate data for the 30-yr mean was obtained from a different climate center near Mead, NE (41 $\left.{ }^{\circ} 24^{\prime \prime} \mathrm{N}, 96^{\circ} 28^{\prime} 48^{\prime \prime} \mathrm{W}\right)$ between 1971 and 2000 (long-term data from the University of Nebraska Turf farm was unavailable).

Three (2009) or four (2010 and 2011) aboveground biomass samples were taken from each whole-plot experimental unit before cover crop termination to determine productivity of the cover crop mixtures and weed communities. Samples were combined within each experimental unit, dried at $60^{\circ} \mathrm{C}$ to constant mass

Table 3. Monthly precipitation (precip.) total $(\mathrm{mm})$ and average air temperature (temp.) $\left({ }^{\circ} \mathrm{C}\right)$ for April to September in 2009,2010 , and

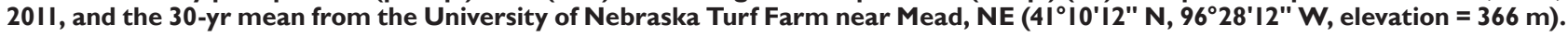

\begin{tabular}{|c|c|c|c|c|c|c|c|c|}
\hline \multirow[b]{3}{*}{ Month } & \multicolumn{8}{|c|}{ Year } \\
\hline & \multicolumn{2}{|c|}{2009} & \multicolumn{2}{|c|}{2010} & \multicolumn{2}{|c|}{2011} & \multicolumn{2}{|c|}{ 30-yr mean } \\
\hline & Temp. & Precip. & Temp. & Precip. & Temp. & Precip. & Temp. & Precip. \\
\hline April & 9.0 & 28 & 12.8 & 85 & 9.9 & 76 & 10.1 & 70 \\
\hline May & 16.9 & 34 & 15.6 & 53 & 16.2 & 164 & 16.3 & 106 \\
\hline June & 21.4 & 135 & 22.5 & 217 & 22.3 & 139 & 22.0 & 101 \\
\hline July & 21.1 & 68 & 24.4 & 156 & 26.5 & 80 & 24.3 & 84 \\
\hline August & 20.9 & 135 & 24.3 & 71 & 23.2 & 78 & 22.9 & 85 \\
\hline September & 17.2 & 31 & 17.4 & 134 & 15.7 & 9 & 18.2 & 73 \\
\hline Total & 17.8 & 432 & 19.5 & 717 & 19.0 & 547 & 19.0 & 519 \\
\hline
\end{tabular}


Table 4. Economic costs, returns, and average annual profit (U.S. dollars (\$) ha-1) for the II different cover crop mixture by termination method treatment combinations in corn, soybean, and sunflower for the years 2009, 2010, 20II, and for the entire rotation. NC = no cover control; WD = weedy mixture; 2-, 4-, 6-, and 8CC = two, four, six, and eight cover crop species mixtures, respectively (Table I); $D$ = disk termination; $U$ = undercutter termination.

\begin{tabular}{|c|c|c|c|c|c|c|c|c|c|c|c|}
\hline \multirow[b]{3}{*}{ Crop/year } & \multirow[b]{3}{*}{ NC } & \multicolumn{8}{|c|}{ Cover crop mixture and termination method } & \multirow{2}{*}{\multicolumn{2}{|c|}{$8 C C$}} \\
\hline & & \multicolumn{2}{|c|}{ WD } & \multicolumn{2}{|c|}{$2 \mathrm{CC}$} & \multicolumn{2}{|c|}{ 4CC } & \multicolumn{2}{|c|}{ 6CC } & & \\
\hline & & D & $\mathbf{U}$ & D & $\mathbf{U}$ & D & $\mathbf{U}$ & D & $\mathbf{U}$ & D & $\mathbf{U}$ \\
\hline & & & & 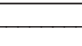 & 1 & Dllars ( & $a^{-1}$ & & & & - \\
\hline \multicolumn{12}{|l|}{$\underline{\text { Costs }}$} \\
\hline 2009 & 1514 & 1472 & 1470 & 1667 & 1665 & 1656 & 1653 & 1690 & 1688 & 1690 & 1688 \\
\hline 2010 & 771 & 731 & 729 & 900 & 897 & 912 & 909 & 954 & 951 & 961 & 959 \\
\hline 2011 & 771 & 731 & 729 & 899 & 897 & 912 & 909 & 954 & 951 & 961 & 959 \\
\hline \multicolumn{12}{|l|}{ Returns } \\
\hline \multicolumn{12}{|l|}{ Corn } \\
\hline 2009 & 3884 & 3404 & 4055 & 3404 & 4055 & 3404 & 4055 & 3404 & 4055 & 3404 & 4055 \\
\hline 2010 & 2193 & 2674 & 3212 & 2674 & 3212 & 2674 & 3212 & 2674 & 3212 & 2674 & 3212 \\
\hline 2011 & 4609 & 4211 & 4547 & 4211 & 4547 & 4211 & 4547 & 4211 & 4547 & 4211 & 4547 \\
\hline \multicolumn{12}{|l|}{ Soybean } \\
\hline 2009 & 1933 & 1179 & 1836 & 1179 & 1836 & 1179 & 1836 & 1179 & 1836 & 1179 & 1836 \\
\hline 2010 & 508 & 578 & 783 & 578 & 783 & 578 & 783 & 578 & 783 & 578 & 783 \\
\hline 2011 & 1755 & 1475 & 2069 & 1475 & 2069 & 1475 & 2069 & 1475 & 2069 & 1475 & 2069 \\
\hline \multicolumn{12}{|l|}{ Sunflower } \\
\hline 2009 & |59| & 1394 & 1540 & 1394 & 1540 & 1394 & 1540 & 1394 & 1540 & 1394 & 1540 \\
\hline 2010 & 401 & 540 & 540 & 540 & 540 & 540 & 540 & 540 & 540 & 540 & 540 \\
\hline 2011 & 1065 & 1021 & 1109 & $|02|$ & 1109 & $102 \mid$ & 1109 & $102 \mid$ & 1109 & $102 \mid$ & 1109 \\
\hline \multicolumn{12}{|l|}{ Avg. annual profit } \\
\hline Corn & 2543 & 2451 & 2962 & 2274 & 2785 & 2270 & 2781 & 2230 & $274 I$ & 2225 & 2736 \\
\hline Soybean & 380 & 99 & 587 & -78 & 410 & -82 & 406 & -122 & 366 & -127 & 361 \\
\hline Sunflower & I & 7 & 87 & $-|7|$ & -90 & -175 & -94 & -214 & -134 & -219 & -139 \\
\hline 3-crop rotation & 975 & 853 & 1212 & 675 & 1035 & 671 & 1031 & 631 & 991 & 626 & 986 \\
\hline
\end{tabular}

and weighed. The biomass harvest area included three 0.3 by $0.3 \mathrm{~m}$ samples per experimental unit in 2009 , and was increased to four 0.3 by $0.6 \mathrm{~m}$ samples per experimental unit in 2010 and 2011 .

Surface soil moisture $(0-8 \mathrm{~cm})$ was measured weekly from cover crop planting through the vegetative growth of the main crop. Measurements were taken at three random points within each whole-plot (before cover crop termination) or split-plot (after cover crop termination) experimental unit using a Theta Probe soil water sensor (SM 200 Soil Moisture Sensor, Delta-T Devices Ltd, Cambridge, UK). Accuracy of the soil water sensor was verified against 21 gravimetric soil samples in 2010 and the ratio between method outputs was approximately 1:1. Linear regression analysis indicated a positive relationship between outputs from the two methods $\left(p=0.003, F=11.68, \mathrm{df}_{\mathrm{n}}=1, \mathrm{df}_{\mathrm{d}}=19, R^{2}=0.38\right)$.

Soil samples were collected twice during each year to characterize early (between 25 and 42 days after termination, DAT) and late (between 55 and 81 DAT) growing season $\mathrm{NO}_{3}-\mathrm{N}$ availability. A composite soil sample of three (2009) or four (2010 and 2011) soil cores $(3.18 \mathrm{~cm}$ diam. by $20 \mathrm{~cm})$ per split-plot experimental unit were taken. Composite soil samples were then air-dried and sent to Ward Laboratories (Ward Laboratories, Kearney, NE) for extraction and analysis of soil $\mathrm{NO}_{3}-\mathrm{N}$. Soil $\mathrm{NO}_{3}-\mathrm{N}$ was extracted with a $\mathrm{Ca}$ solution and analyzed by the $\mathrm{Cd}$ reduction procedure (Ward, 2011).

Crop yield was determined for each main crop by harvesting seed or grain from the middle three (corn) or four (soybean and sunflower) rows of each split-plot experimental unit. Contents were weighed using a combine scale (Model 400, Weigh-Tronix, Fairmont, MN) and adjusted for moisture content in the lab. Corn grain yields were adjusted to 0.155 , soybean to 0.130 , and sunflower to $0.10 \mathrm{~g} \mathrm{~kg}^{-1}$ moisture. After crop yields were determined, economic costs and returns were calculated for each crop- cover crop mixture- termination method treatment combination for each year. The difference of returns less costs was considered profit and calculated on an average annual basis for each crop and the entire rotation (Table 4). Cost estimates (e.g., seed, custom planting, cultivation, and harvest, etc.) were obtained from a variety of sources. Costs were considered fixed across crops and years and only varied due to the cost of each cover crop mixture and manure applied before the 2009 cropping season (Tables 4 and 5). Similarly, one price estimate was used for each crop return; thus, annual returns only varied according to the yield of each crop among treatments where significant yield differences occurred.

\section{Data Analysis}

Values for cover crop biomass, soil moisture, soil $\mathrm{NO}_{3}-\mathrm{N}$, and crop yield were analyzed with a linear mixed model analysis of variance using the GLIMMIX procedure in SAS 9.2 (SAS Institute, Cary, NC). Fixed effects in the model included main crop, cover crop mixture, termination method, and all possible interactions of these effects. The random effects were block and the interaction of block $\times$ current crop $\times$ cover crop mixture. The model for data taken before cover crop termination (i.e., cover crop biomass and soil moisture) excluded fixed effects for main crop and termination method. In addition, models for soil $\mathrm{NO}_{3}-\mathrm{N}$ and soil moisture analysis included a fixed effect for and interactions including day of year (DOY). Effects were often tested within individual years due to experimental changes in the cover crop mixture (buckwheat [Fagopyrum sagittatum Moench] was replaced in all mixtures with Idagold mustard [Sinapis alba L.] after 2009 due to poor growth of buckwheat) and interactions with year when initially included as a fixed effect (data not shown). Least square means and standard errors were calculated for all significant fixed effects at an $\alpha$ level of 
Table 5. Price estimates and information source for costs and returns associated with each experimental management system.

\begin{tabular}{|c|c|c|}
\hline Costs and returns & U.S. dollars ha-1 & Source \\
\hline \multicolumn{3}{|l|}{ Costs } \\
\hline \multicolumn{3}{|l|}{ Cover crop seed } \\
\hline Idagold mustard & 83 & L.A. Hearne \\
\hline Buckwheat $\ddagger$ & 178 & Johnny’s Selected Seeds§ \\
\hline Hairy vetch $\ddagger$ & 118 & L.A. Hearne $\dagger$ \\
\hline Pacific Gold mustard & 51 & L.A. Hearne $\dagger$ \\
\hline Field peał & 195 & L.A. Hearne \\
\hline Oilseed radish & 115 & Johnny’s Selected Seeds§ \\
\hline Crimson clover $\ddagger$ & 363 & Johnny’s Selected Seeds§ \\
\hline Dwarf essex rape & 52 & Johnny's Selected Seeds§ \\
\hline Chickling vetch $\ddagger$ & 298 & Johnny's Selected Seeds§ \\
\hline Land rent & 445 & University of Nebraska-Lincoln Extension (20II) \\
\hline \multicolumn{3}{|l|}{ Cover crop planting } \\
\hline Seedbed preparation & 17 & Jose and Janousek (2010) \\
\hline Drill planting & 30 & Jose and Janousek (2010) \\
\hline \multicolumn{3}{|l|}{ Cover crop termination } \\
\hline Disking & 25 & Jose and Janousek (2010) \\
\hline Undercutting & 22 & Jose and Janousek (2010) \\
\hline \multicolumn{3}{|l|}{ Main crop planting } \\
\hline Seedbed preparation & 17 & Jose and Janousek (2010) \\
\hline Organic crop seed & 74 & Delate et al. (2003) \\
\hline Planting & 34 & Jose and Janousek (2010) \\
\hline \multicolumn{3}{|l|}{ Weed management } \\
\hline Interrow cultivation & 22 & Jose and Janousek (2010) \\
\hline Combine harvest & 69 & Jose and Janousek (2010) \\
\hline \multicolumn{3}{|l|}{ Fall tillage } \\
\hline Moldboard plow & 22 & Jose and Janousek (2010) \\
\hline Feedlot manure & 741 & Delate et al. (2003) \\
\hline Certification costs & 40 & North Carolina State University Extension (2008) \\
\hline \multicolumn{3}{|l|}{ Returns } \\
\hline Corn $\ddagger$ & $\$ 433 \mathrm{Mg}^{-1}$ & USDA Market News Service (2012) \\
\hline Soybean $\ddagger$ & $\$ 698 \mathrm{Mg}^{-1}$ & USDA Market News Service (2012) \\
\hline Sunflower & $\$ 295 \mathrm{Mg}^{-1}$ & National Sunflower Association (20I2) \\
\hline
\end{tabular}

$\dagger$ L.A. Hearne Co., Monterey County, CA.

$\ddagger$ Certified organic.

$\S$ Johnny's Selected Seeds, Fairfield, ME.

0.05. To aid in the visualization of statistical interactions, cover crop biomass data have been plotted as lines with cover crop mixture on the $x$ axis and the cover crop treatments arranged in order (left to right) of increasing species diversity along the $x$ axis (Tilman et al., 2001; Sosnoskie et al., 2006).

\section{RESULTS AND DISCUSSION}

\section{Climate}

The average daily air temperature during the growing season for cover crops and summer annual cash crops (1 April-30 September) was $17.8,19.5$, and $19.0^{\circ} \mathrm{C}$ in the years 2009,2010 , and 2011, respectively (Table 3). The 30-yr mean (1971-2000) air temperature for the growing season near Mead, NE, was $19.0^{\circ} \mathrm{C}$. The 2009 growing season was exceptionally cool, especially during early cover crop growth (April) and vegetative crop growth (June through August; Table 3). Average total precipitation during the growing season for cover crops and summer annual cash crops was 432, 717, and $547 \mathrm{~mm}$ in 2009,2010 , and 2011, respectively. The 30-yr mean total precipitation was $519 \mathrm{~mm}$ (Table 3). In addition to abnormally cool temperatures, the 2009 growing season was also relatively dry, especially during cover crop growth and early cash crop establishment. As a result, plant water stress (e.g., curling and cupping of leaves) was observed in all crops during June of 2009.

\section{Cover Crop Productivity}

Total cover crop mixture and/or weed biomass was greatest in the 6CC treatment $\left(328.2 \pm 21.0 \mathrm{~g} \mathrm{~m}^{-2}\right)$, followed by the $4 \mathrm{CC}\left(287.6 \pm 20.1 \mathrm{~g} \mathrm{~m}^{-2}\right), 8 \mathrm{CC}(260.6 \pm$ $\left.20.1 \mathrm{~g} \mathrm{~m}^{-2}\right), 2 \mathrm{CC}\left(155.0 \pm 20.1 \mathrm{~g} \mathrm{~m}^{-2}\right)$ and WD $\left(73.7 \mathrm{~g} \mathrm{~m}^{-2} \pm 20.1 \mathrm{~g} \mathrm{~m}^{-2}\right)$ treatments (LS mean \pm standard error) when harvested $60 \mathrm{~d}$ after cover crop planting in 2009

(Fig. 1). Cover crop productivity was not different among cover crop mixtures (ranging from 367.2 to $409.3 \pm 16.7 \mathrm{~g} \mathrm{~m}^{-2}$ ), but was lowest in the WD treatment $\left(68.8 \pm 16.7 \mathrm{~g} \mathrm{~m}^{-2}\right)$ when harvested $55 \mathrm{~d}$ after cover crop planting in 2010 (Fig. 1). Consistent with trends in 2009, cover crop productivity in 2011 was greatest in the 6CC, 8CC, and 4CC treatments (309.6, 307.2 , and $276.2 \pm 14.3 \mathrm{~g} \mathrm{~m}^{-2}$, respectively), followed by the 2CC treatment (205.2 \pm $14.3 \mathrm{~g} \mathrm{~m}^{-2}$ ), and lowest in the WD treatment $\left(120.4 \pm 14.3 \mathrm{~g} \mathrm{~m}^{-2}\right)$. Biomass of weeds in the WD treatment was lower than biomass of cover crop mixtures primarily due to spatial heterogeneity of weeds growing in this treatment and variable emergence and growth of various species in the weed community. Though the productivity of cover crop mixtures was similar in 2009 and 2011, the cause for this response was different between years.

Differences in cover crop productivity in 2009 were likely due to the presence or absence of a mustard species (Brassicaceae spp.) in the mixture. Cover crop biomass was lowest in the 2CC mixture as it only included hairy vetch and buckwheat. Both of these species were slow growing throughout the relatively cool and dry early growing season in 2009 (Table 3), and buckwheat was moderately susceptible to early frost. Buckwheat is often used as a summer cover crop or later planted main crop due to its susceptibility to frost, especially during seedling growth (Kalinova and Moudry, 2003); thus, buckwheat may not be a suitable species for use as a spring-sown cover crop in the western Corn Belt. Given these results, buckwheat was replaced in all mixtures with Idagold mustard in 2010 and 2011. Idagold mustard was selected as the replacement due to the high level of productivity of the three other mustard species used in the 4CC, 6CC, and 8CC mixtures in 2009. Mustard species, including Idagold mustard, are well adapted to the cool climate of the northern Great Plains, and productivity is often maximized when planting between mid-March and mid-April (Chen et al., 2005). Given the productivity of the mustard species used in this study, it is not surprising that biomass was not different among cover crop mixtures in 2010 when all mixtures contained a 1:1 ratio of mustard and legume species.

While cover crop productivity responded positively to the mixture adjustments in 2010, it was a May 2011 hail storm that led to 2011 


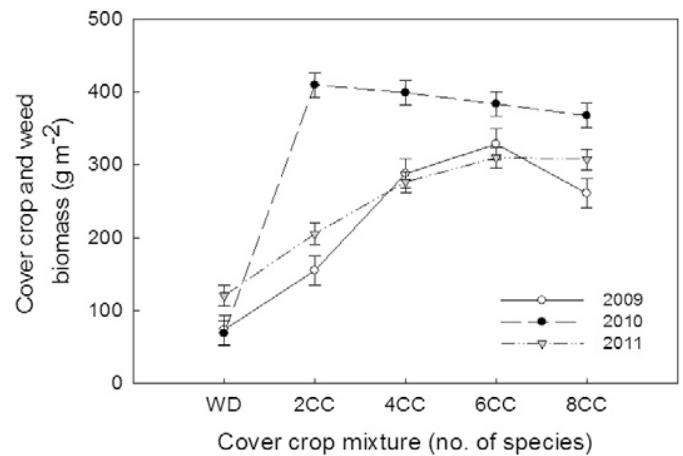

Fig. I. Cover crop and/or weed biomass combined $\left(\mathrm{g} \mathrm{m}^{-2}\right)$ for each cover crop mixture treatment in years 2009, 2010, and 2011 of the study. Mixtures are arranged on the $x$ axis in order of increasing cover crop community diversity. WD = weedy mixture; 2-, 4-, 6-, and 8CC = two, four, six, and eight cover crop species mixtures, respectively (Table I).

treatment differences. The hail storm damaged all cover crop species within mixtures, but Idagold mustard was most susceptible to hail damage and did not recover well from this extreme disturbance (Wortman et al., 2012). Idagold mustard was a component of all four cover crop mixtures; thus, as the diversity of the cover crop mixture increased, the proportion of Idagold mustard in the mixture decreased. Therefore, we hypothesize that productivity of the mixtures increased with diversity due to decreased proportions of Idagold mustard. These results, in combination with the 2009 results, highlight an important benefit of diverse cover crop mixtures. By reducing the proportion of each species in a diverse cover crop mixture, we observed increased resilience and productivity of the cover crop community despite a management error (2009) and extreme weather disturbance (2011). Similar to a diversified investment portfolio, diverse cover crop mixtures seem poised for stable productivity and resilience despite potential management errors and an increasingly unstable climate (Doak et al., 1998).

\section{Surface Soil Moisture}

Surface soil moisture $(0-8 \mathrm{~cm})$ before cover crop termination was unaffected by cover crop mixture diversity, but by DOY 141 soil moisture content was greatest in the $\mathrm{NC}$ control $\left(0.310 \pm 0.007 \mathrm{~cm}^{3} \mathrm{H}_{2} \mathrm{O} \mathrm{cm}^{-3}\right.$ soil), followed by the WD treatment $(0.20 \pm$ $\left.0.007 \mathrm{~cm}^{3} \mathrm{~cm}^{-3}\right)$ in $2009(p<0.0001$; Fig. 2). Soil moisture was lowest in the cover crop mixtures $\left(0.161 \mathrm{~cm}^{3} \mathrm{~cm}^{-3}\right.$ averaged across the four mixtures). The reduction in soil moisture in cover-cropped and weedy treatments by DOY 141 was related to an exceptionally dry early spring in 2009. Between DOY 110 and 145 there were only two rainfall events totaling more than $10 \mathrm{~mm}$ in precipitation, and total precipitation during April and May was $62 \mathrm{~mm}$. The 30-yr mean for precipitation in April and May was $176 \mathrm{~mm}$ (Table 3). These results highlight the risk associated with planting cover crops in non-irrigated grain-based production systems (Ewing et al., 1991). While average annual precipitation is typically sufficient for growth of both a cover crop and cash crop, exceptionally dry years may cause significant production challenges and potential yield loss. Following cover crop termination, surface soil moisture was influenced by the interaction of DOY and termination method in $2009(p=0.001)$. Surface soil moisture was greatest in the $\mathrm{NC}$ control $\left(0.249 \mathrm{~cm}^{3} \mathrm{~cm}^{-3} \pm\right.$ $0.005)$, followed by the undercutter treatment $\left(0.160 \mathrm{~cm}^{3} \mathrm{~cm}^{-3} \pm\right.$ $0.002)$, and lowest in the disk treatment $\left(0.153 \mathrm{~cm}^{3} \mathrm{~cm}^{-3} \pm\right.$ 0.002) $1 \mathrm{wk}$ following termination (DOY 149; Fig. 2). However, by DOY 183 surface moisture was greatest in the undercutter treatment $\left(0.112 \mathrm{~cm}^{3} \mathrm{~cm}^{-3} \pm 0.002\right)$, followed by the NC control $\left(0.103 \mathrm{~cm}^{3} \mathrm{~cm}^{-3} \pm 0.005\right)$, and lowest in the disk treatment $\left(0.095 \mathrm{~cm}^{3} \mathrm{~cm}^{-3} \pm 0.002\right)$. At this point in the growing season, all crops were showing severe water stress. While soil moisture was exceptionally low among all treatments, it is interesting that soil moisture was greatest in the undercutter treatment at DOY 183 despite 56\% less available moisture than the NC control at DOY 149.

Similar to 2009 results, surface soil moisture was unaffected by cover crop mixture diversity before cover crop termination in 2010. However, surface soil moisture was greatest in both the $\mathrm{NC}$ control $\left(0.259 \mathrm{~cm}^{3} \mathrm{~cm}^{-3} \pm 0.006\right)$ and the WD treatment $\left(0.255 \mathrm{~cm}^{3} \mathrm{~cm}^{-3} \pm 0.006\right)$ at DOY 126 ( $p=0.001$; Fig. 3). Variable soil moisture in the cover-cropped treatments throughout cover crop growth was related to rainfall patterns in early 2010 . While soil moisture content was reduced in cover-cropped treatments at DOY 126, four rainfall events totaling $33.8 \mathrm{~mm}$ in precipitation over the next $6 \mathrm{~d}$ was sufficient to eliminate soil moisture differences between cover-cropped and noncover-cropped treatments by DOY 137 (Fig. 3). Following cover crop termination, surface soil moisture was affected by termination method in 2010. Averaged across the first three sampling dates (DOY 158, 166, and 169), surface moisture was greatest in the undercut treatment $(0.330 \pm$ $\left.0.003 \mathrm{~cm}^{3} \mathrm{~cm}^{-3}\right)$ compared to both the $\mathrm{NC}$ and disk treatments $\left(0.314 \pm 0.006 \mathrm{~cm}^{3} \mathrm{~cm}^{-3}\right.$ and $0.306 \pm 0.002 \mathrm{~cm}^{3} \mathrm{~cm}^{-3}$, respectively; $p=0.001$; Fig. 3). We hypothesize that greater soil moisture following termination with the undercutter in 2009 and 2010

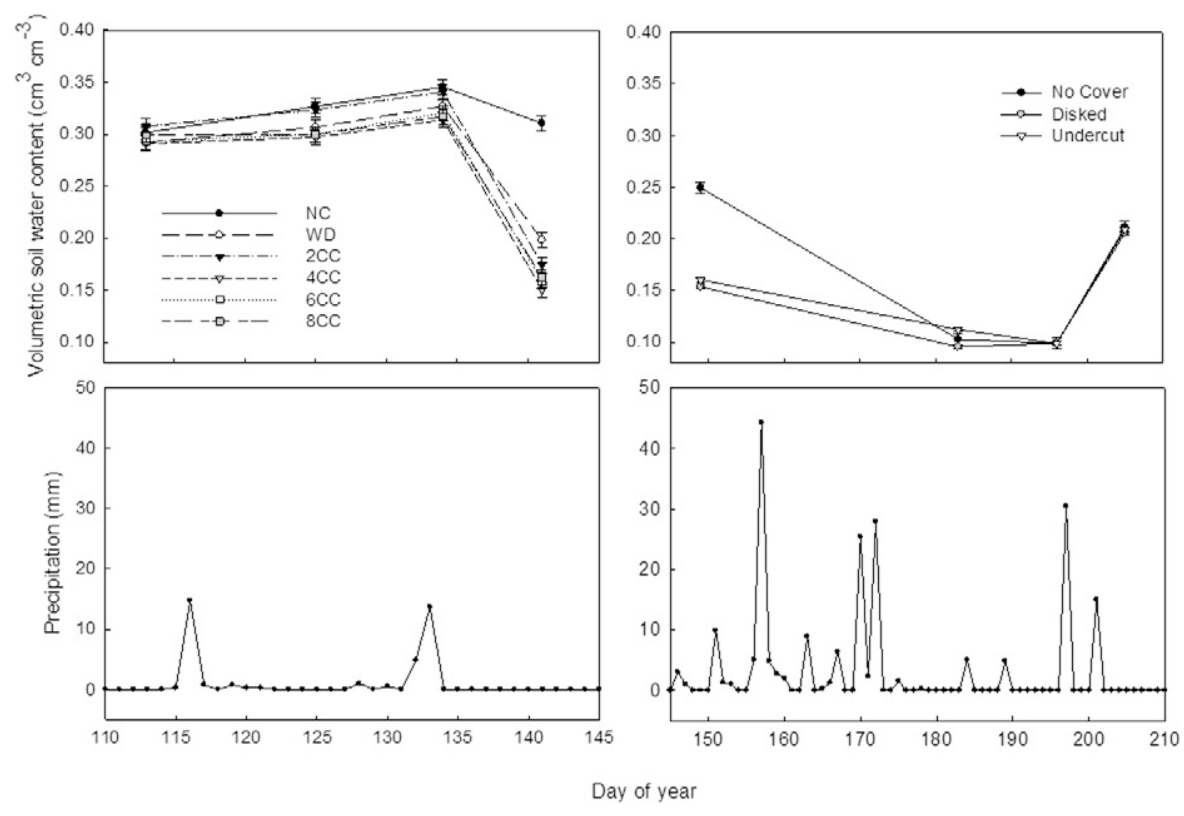

Fig. 2. Volumetric soil water content $\left(\mathrm{cm}^{3} \mathrm{H}_{2} \mathrm{O} \mathrm{cm}^{-3}\right.$ soil) (top left) during cover crop growth (top right) and following cover crop termination in 2009. Daily precipitation totals $(\mathrm{mm})$ for day of year (DOY) 110 to 210 are included (bottom left and right). NC = no cover control; WD = weedy mixture; 2-, 4-, 6-, and 8CC = two, four, six, and eight cover crop species mixtures, respectively (Table I). 
was due to the layer of cover crop mulch present on the soil surface for 14 to $21 \mathrm{~d}$ following termination with the undercutter. This is consistent with previous studies where management of cover crop residue on the soil surface led to increased soil moisture availability (Teasdale and Mohler, 1993; Kornecki et al., 2009; Davis, 2010).

While soil moisture savings associated with the undercutter for fallow tillage have been discussed (Zaikin et al., 2007), to our knowledge this is the first report of increased soil moisture availability following cover crop termination with an undercutter.

Soil moisture content varied by cover crop treatment and DOY before termination in 2011. During early cover crop growth, soil moisture was greatest in the WD and NC treatments ( 0.161 and $0.156 \pm 0.006 \mathrm{~cm}^{3} \mathrm{~cm}^{-3}$, respectively), followed by the cover-crop mixtures (average of $0.127 \pm 0.006 \mathrm{~cm}^{3} \mathrm{~cm}^{-3} ; p=0.0001$; Fig. 4). However, by the end of cover-crop growth (DOY 153) soil moisture content was greatest in the $4 \mathrm{CC}, 6 \mathrm{CC}$, and $8 \mathrm{CC}$ mixtures (average of $\left.0.288 \pm 0.006 \mathrm{~cm}^{3} \mathrm{~cm}^{-3}\right)$, followed by the 2CC mixture $(0.257 \pm$ $\left.0.006 \mathrm{~cm}^{3} \mathrm{~cm}^{-3}\right)$, and the WD and NC treatments $(0.243$ and $0.235 \pm 0.006 \mathrm{~cm}^{3} \mathrm{~cm}^{-3}$, respectively; $p=0.0001$; Fig. 4). May 2011 was exceptionally wet ( $164 \mathrm{~mm}$ precipitation) compared to the $30-\mathrm{yr}$ mean for May $(106 \mathrm{~mm})$, leading to greater surface soil moisture content beneath cover crop canopies (Table 3). When there was sufficient soil moisture to meet cover crop transpiration demands, the dense cover crop canopy may have conserved soil moisture by reducing evaporative loss from the soil surface occurring in the relatively bare NC and WD treatments. Indeed, soil evaporation can be reduced through early crop canopy closure (Leuning et al., 1994). Following cover crop termination in 2011, surface soil moisture was not influenced by the interaction of termination method and $\operatorname{DOY}(p=0.677)$. Instead, soil moisture was influenced by cover crop treatment $(p=0.021)$, where values were greatest in the $8 \mathrm{CC}$ mixture $\left(0.275 \pm 0.004 \mathrm{~cm}^{3} \mathrm{~cm}^{-3}\right)$ and lowest in the NC and WD treatments $\left(0.262 \pm 0.006 \mathrm{~cm}^{3} \mathrm{~cm}^{-3}\right.$ and $0.254 \pm 0.004 \mathrm{~cm}^{3} \mathrm{~cm}^{-3}$, respectively) when pooled across the three post-termination
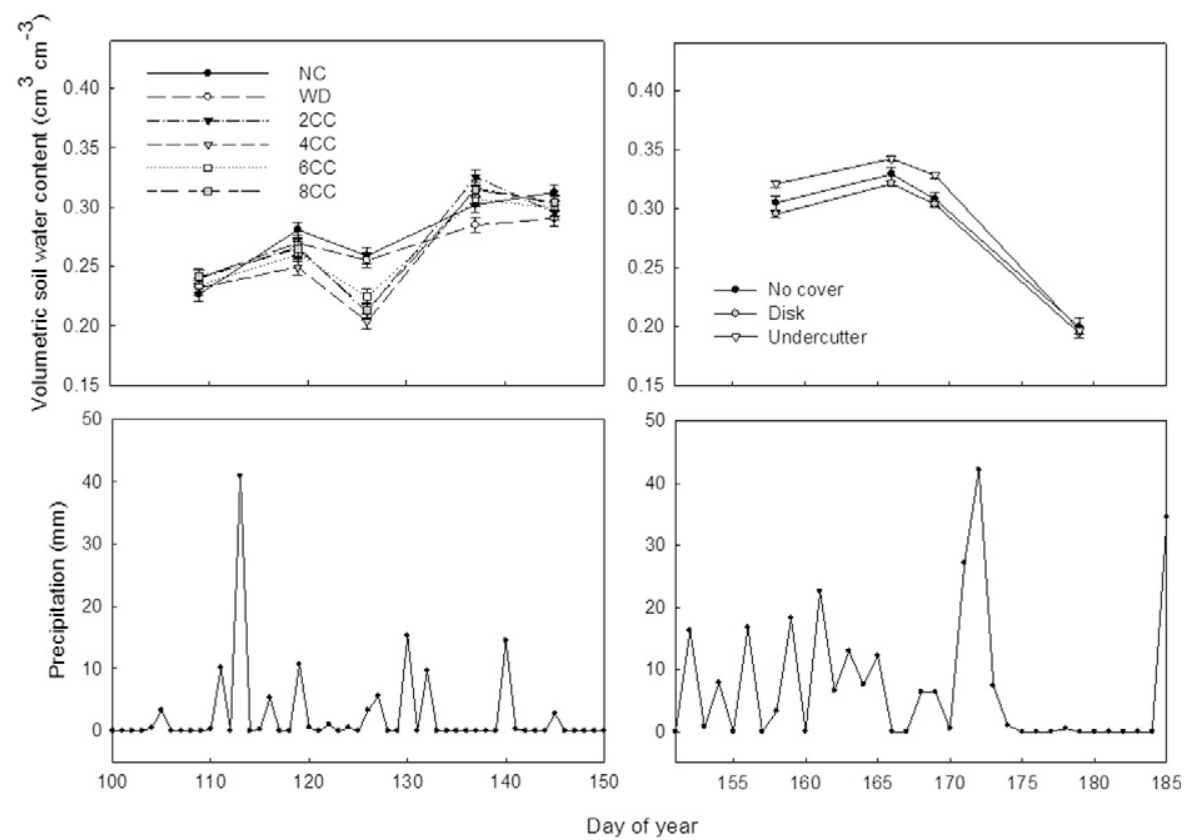

Fig. 3. Volumetric soil water content $\left(\mathrm{cm}^{3} \mathrm{H}_{2} \mathrm{O} \mathrm{cm}^{-3}\right.$ soil) (top left) during cover crop growth and (top right) following cover crop termination in 2010. Daily precipitation totals $(\mathrm{mm})$ for day of year (DOY) 100 to 185 are included (bottom left and right). NC = no cover control; WD = weedy mixture; $2-, 4-, 6-$, and $8 C C=$ two, four, six, and eight cover crop species mixtures, respectively (Table I).
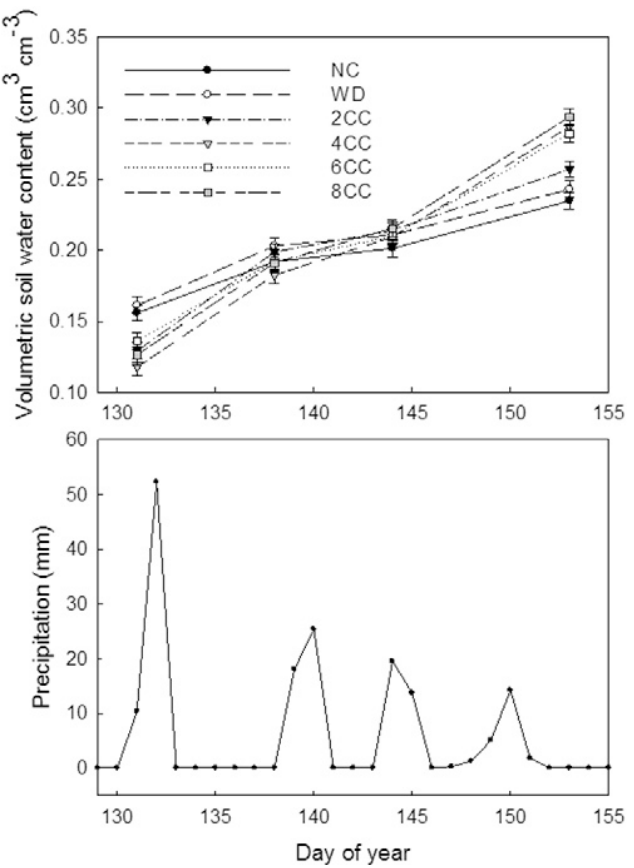

Fig. 4. Volumetric soil water content $\left(\mathrm{cm}^{3} \mathrm{H}_{2} \mathrm{O} \mathrm{cm}^{-3}\right.$ soil) (top) during cover crop growth and (bottom) daily precipitation totals $(\mathrm{mm})$ for day of year (DOY) 129 to 155 in 20II. NC = no cover control; WD = weedy mixture; 2-, 4-, 6-, and 8CC = two, four, six, and eight cover crop species mixtures, respectively (Table I).

sampling intervals (DOY 159-186; data not shown). Increased soil moisture in the cover-cropped treatments in the third year of this study may be related to improvements in soil physical structure. Cover-cropping in organic systems has been shown to increase soil water infiltration and soil water holding capacity (Colla et al., 2000; Lotter et al., 2003).

\section{Soil Nitrogen}

Soil $\mathrm{NO}_{3}-\mathrm{N}$ at 45 and 81 DAT was affected by the interaction of cover crop mixture and termination method in 2009 ( $p=0.038$ and $p=0.006$, respectively). Soil $\mathrm{NO}_{3}-\mathrm{N}$ was greatest in the WD-undercut treatment combination $(50.2 \pm 6.1 \mathrm{mg}$ $\mathrm{NO}_{3}-\mathrm{N} \mathrm{kg}^{-1}$ ), but differences among the remaining cover crop and termination treatments were inconsistent at $45 \mathrm{DAT}$ (data not shown). At $81 \mathrm{DAT}_{\text {soil }} \mathrm{NO}_{3}-\mathrm{N}$ was greatest in the $\mathrm{NC}$ control (30.0 \pm $2.4 \mathrm{mg} \mathrm{NO}^{-}-\mathrm{N} \mathrm{kg}^{-1}$ ), followed by the WD-undercut treatment combination $\left(22.5 \pm 2.4 \mathrm{mg} \mathrm{NO}_{3}-\mathrm{N} \mathrm{kg}^{-1}\right)$. Similar to the results at $45 \mathrm{DAT}$, differences among remaining treatments were inconsistent (data not shown). Increased soil $\mathrm{NO}_{3}-\mathrm{N}$ in the WD and NC treatments at 45 and 81 DAT in 2009 was likely the result of $\mathrm{N}$-immobilization and delayed $\mathrm{NO}_{3}-\mathrm{N}$ mineralization following cover crop growth, termination, and decomposition. Previous studies have demonstrated delayed soil $\mathrm{NO}_{3}-\mathrm{N}$ release from cover crop residue 
especially following late termination (Wagger, 1989; Quemada and Cabrera, 1995; Kuo and Sainju, 1998). Moreover, N immobilization is most pronounced when cover crop residue is comprised of more than 60\% nonleguminous residue (Kuo and Sainju, 1998). In this study, mustard species dominated the mixtures and typically accounted for more than $60 \%$ of total mixture biomass (Wortman et al., 2012).

Following the 2008 growing season, the experimental site was amended with $50 \mathrm{Mg} \mathrm{ha}^{-1}$ beef feedlot liquid manure. While available soil $\mathrm{NO}_{3}-\mathrm{N}$ was greatest in the $\mathrm{NC}$ and WD treatments throughout the 2009 growing season, the immobilization of soil $\mathrm{NO}_{3}-\mathrm{N}$ in cover crop residue likely reduced $\mathrm{NO}_{3}-\mathrm{N}$ leaching and surface runoff from the manure early in the growing season (Staver and Brinsfield, 1998). Moreover, lower levels of available soil $\mathrm{NO}_{3}-\mathrm{N}$ in the cover-cropped treatments early in the growing season may have aided in the suppression of weeds. High levels of available soil $\mathrm{N}$ have been shown to shift the competitive advantage to weed species especially following manure application (Barker et al., 2006; Wortman et al., 2011).

Soil $\mathrm{NO}_{3}-\mathrm{N}$ at $32 \mathrm{DAT}$ was affected by cover crop termination method in 2010 ( $p=0.006)$, as soil $\mathrm{NO}_{3}-\mathrm{N}$ was greatest in the undercutter treatment $\left(3.2 \pm 0.2 \mathrm{mg} \mathrm{NO}_{3}-\mathrm{N} \mathrm{kg}^{-1}\right)$, followed by both the disk $\left(2.2 \pm 0.2 \mathrm{mg} \mathrm{NO}_{3}-\mathrm{N} \mathrm{kg}^{-1}\right)$ and $\mathrm{NC}$ treatments $\left(2.2 \pm 0.4 \mathrm{mg} \mathrm{NO}_{3}-\mathrm{N} \mathrm{kg}^{-1}\right)$. By $60 \mathrm{DAT}$, soil $\mathrm{NO}_{3}-\mathrm{N}$ levels were only influenced by main crop $(p=0.038)$. Soil $\mathrm{NO}_{3}-\mathrm{N}$ was greatest in soybean $\left(5.0 \pm 0.2 \mathrm{mg} \mathrm{NO}_{3}-\mathrm{N} \mathrm{kg}^{-1}\right)$, followed by corn $\left(4.4 \pm 0.2 \mathrm{mg} \mathrm{NO}_{3}-\mathrm{N} \mathrm{kg}^{-1}\right)$, and sunflower $(4.0 \pm 0.2 \mathrm{mg}$ $\left.\mathrm{NO}_{3}-\mathrm{N} \mathrm{kg}^{-1}\right)$. Results for soil $\mathrm{NO}_{3}-\mathrm{N}$ in 2011 were similar to 2010, except that treatment differences were not observed until later in the growing season. Soil $\mathrm{NO}_{3}-\mathrm{N}$ was influenced by cover crop termination $(p=0.035)$ with the greatest levels observed in the undercutter treatment $\left(11.4 \pm 0.5 \mathrm{mg} \mathrm{NO}_{3}-\mathrm{N} \mathrm{kg}^{-1}\right)$, followed by the disk and $\mathrm{NC}$ treatments $\left(9.6 \pm 0.5 \mathrm{mg} \mathrm{NO}_{3}-\mathrm{N} \mathrm{kg}^{-1}\right.$ and $8.4 \pm 1.3 \mathrm{mg} \mathrm{NO}_{3}-\mathrm{N} \mathrm{kg}^{-1}$, respectively) at 55 DAT in 2011 . Also consistent with 2010 results, soil $\mathrm{NO}_{3}-\mathrm{N}$ was greatest in soybean $\left(12.4 \pm 0.6 \mathrm{mg} \mathrm{NO}_{3}-\mathrm{N} \mathrm{kg}^{-1}\right)$, followed by corn $(11.3 \pm$ $\left.0.6 \mathrm{mg} \mathrm{NO}_{3}-\mathrm{N} \mathrm{kg}^{-1}\right)$, and sunflower $\left(7.1 \pm 0.6 \mathrm{mg} \mathrm{NO}_{3}-\mathrm{N} \mathrm{kg}^{-1}\right.$; $p<0.0001)$. As expected, soil $\mathrm{NO}_{3}-\mathrm{N}$ levels were generally lower in 2010 and 2011 compared to 2009, presumably the result of grain $\mathrm{N}$ removal. As soil $\mathrm{N}$ becomes limiting with time, management focus should shift from minimizing $\mathrm{NO}_{3}-\mathrm{N}$ leaching and runoff toward maximizing availability. The lower soil $\mathrm{NO}_{3}-\mathrm{N}$ observed in the disk treatment compared to the undercut treatment at 29 DAP in 2010 was likely the result of strong $\mathrm{N}$ immobilization that is common following soil incorporation of cover crops (Wyland et al., 1995). In contrast, cover crop surface residue mulch achieved with the undercutter may result in lower immobilization and a more gradual release of soil $\mathrm{NO}_{3}-\mathrm{N}$ throughout the growing season (Groffman et al., 1987; Parr et al., 2011).

\section{Crop Yield}

Crop yield for corn, sunflower, and soybean were affected by cover crop termination method but not cover crop mixture in 2009. Corn grain yield was greater in the undercutter treatment $\left(8.78 \pm 0.36 \mathrm{Mg} \mathrm{ha}^{-1}\right)$ compared to the disk treatment $\left(7.37 \pm 0.36 \mathrm{Mg} \mathrm{ha}^{-1}\right)$, while yield in the NC control was not different from either termination treatment (Table 6). Similarly, sunflower seed yield was greater in the undercutter treatment $\left(2.11 \pm 0.09 \mathrm{Mg} \mathrm{ha}^{-1}\right)$ compared to the disk treatment $\left(1.91 \pm 0.09 \mathrm{Mg} \mathrm{ha}^{-1}\right)$, while yield in the NC control was not different from either termination treatment (Table 6). Soybean seed yield was greater in the undercutter and NC treatments $(2.43 \pm 0.09$ and $2.59 \pm 0.21 \mathrm{Mg} \mathrm{ha}^{-1}$, respectively) compared to the disk treatment $\left(1.50 \pm 0.09 \mathrm{Mg} \mathrm{ha}^{-1}\right.$; Table 6).

Similarly, crop yield in 2010 was affected by cover crop termination method, not cover crop mixture. Corn yield was greatest in the undercutter treatment $\left(7.75 \pm 0.25 \mathrm{Mg} \mathrm{ha}^{-1}\right)$, followed by the disk treatment $\left(6.45 \pm 0.25 \mathrm{Mg} \mathrm{ha}^{-1}\right)$, and lowest in the NC control (5.29 $\pm 0.60 \mathrm{Mg} \mathrm{ha}^{-1}$; Table 6). Soybean yield was also greatest in the undercutter treatment $\left(1.11 \pm 0.09 \mathrm{Mg} \mathrm{ha}^{-1}\right)$, but was not different between the disk and NC treatments. Sunflower yield was not affected by termination method in 2010 (Table 6). Overall, crop yields in 2011 were greater than those in 2009 and 2010. Consistent with previous years, yield was only influenced by the effect of cover crop termination. Corn grain yield was greatest in the $\mathrm{NC}$ and undercutter treatments $(11.12 \pm 0.64$ and $10.97 \pm 0.28 \mathrm{Mg} \mathrm{ha}^{-1}$, respectively) and lowest in the disk treatment $\left(10.16 \pm 0.28 \mathrm{Mg} \mathrm{ha}^{-1}\right)$. Soybean yield was greatest in the undercutter treatment $\left(2.96 \pm 0.08 \mathrm{Mg} \mathrm{ha}^{-1}\right)$, followed by the $\mathrm{NC}$ control $\left(2.51 \pm 0.18 \mathrm{Mg} \mathrm{ha}^{-1}\right)$, and lowest in the disk treatment $\left(2.11 \pm 0.08 \mathrm{Mg} \mathrm{ha}^{-1}\right)$. Consistent with 2010 , there were no treatment effects on sunflower yield in 2011 (Table 6).

Difference in yield among years was the result of unique weather and pest incidence in each year of the study. The sharp decline in crop yield from 2009 to 2010 was the result of crop damage from a severe hail storm on 13 Sept. 2010 at the experimental site. During this storm, all plants were completely defoliated (95-100\%) and severely lodged ( $>50 \%$ ) before physiological maturity (data not shown). The timing of the hail damage was especially detrimental to soybean, as soybean yield can be reduced by as much as $57 \%$ after full defoliation in late reproductive stages (Caviness and Thomas, 1980). Yield loss in corn and sunflower was more related to plant lodging and ear/head dropping (data not shown). Despite overall yield reduction, damage throughout the field was relatively uniform and comparisons among treatments were still informative. Corn yield loss in 2009 relative to 2011 was likely due to a reduction in grain quality in 2009 . The test weight for corn grain was $650 \pm 2 \mathrm{~kg} \mathrm{~m}^{-3}$ in 2009 compared to $724 \pm 2 \mathrm{~kg} \mathrm{~m}^{-3}$ in 2011 . Lower test weight values in 2009 were the result of an early frost on 4 Oct. 2009

Table 6. Crop yield $\left(\mathrm{Mg} \mathrm{ha}^{-1}\right) \pm$ I standard error for corn, soybean, and sunflower as influenced by termination method in the years 2009, 2010, and 20II. Different letters within a particular year and crop indicate differences among termination methods.

\begin{tabular}{lccc}
\hline \multirow{2}{*}{ Crop } & \multicolumn{3}{c}{ Year } \\
\cline { 2 - 4 } Corn & $\mathbf{2 0 0 9}$ & $\mathbf{2 0 1 0}$ & $\mathbf{2 0 I I}$ \\
\cline { 2 - 4 } & & $\mathrm{Mg} \mathrm{ha}^{-1}$ & \\
No cover & $8.41 \pm 0.64 \mathrm{a}$ & $5.29 \pm 0.64 \mathrm{c}$ & $11.12 \pm 0.64 \mathrm{a}$ \\
Disk & $7.37 \pm 0.28 \mathrm{~b}$ & $6.45 \pm 0.28 \mathrm{~b}$ & $10.16 \pm 0.28 \mathrm{~b}$ \\
Undercutter & $8.78 \pm 0.28 \mathrm{a}$ & $7.75 \pm 0.28 \mathrm{a}$ & $10.97 \pm 0.28 \mathrm{a}$ \\
Soybean & & & \\
No cover & $2.59 \pm 0.18 \mathrm{a}$ & $0.72 \pm 0.18 \mathrm{~b}$ & $2.51 \pm 0.18 \mathrm{~b}$ \\
Disk & $1.58 \pm 0.08 \mathrm{~b}$ & $0.82 \pm 0.08 \mathrm{~b}$ & $2.11 \pm 0.08 \mathrm{c}$ \\
Undercutter & $2.46 \pm 0.08 \mathrm{a}$ & $1.11 \pm 0.08 \mathrm{a}$ & $2.96 \pm 0.08 \mathrm{a}$ \\
Sunflower & & & \\
No cover & $2.18 \pm 0.15 \mathrm{a}$ & $0.55 \pm 0.15 \mathrm{a}$ & $1.46 \pm 0.15 \mathrm{a}$ \\
Disk & $1.91 \pm 0.07 \mathrm{~b}$ & $0.74 \pm 0.07 \mathrm{a}$ & $1.40 \pm 0.07 \mathrm{a}$ \\
Undercutter & $2.11 \pm 0.07 \mathrm{a}$ & $0.74 \pm 0.07 \mathrm{a}$ & $1.52 \pm 0.07 \mathrm{a}$ \\
\hline
\end{tabular}


(low temperature of $-1.7^{\circ} \mathrm{C}$ ), which occurred before physiological maturity of the corn crop. When planting a spring-seeded cover crop in the western Corn Belt, it will often be necessary to delay traditional planting dates of corn and soybean. However, the yield loss observed in 2009 highlights the importance of selecting appropriate early-maturing hybrids and crop cultivars to avoid further reductions in crop yield and quality associated with a later planting date.

Sunflower yield loss in 2010 and 2011, relative to 2009 was primarily due to high incidence of banded sunflower moth (Cochylis hospes) damage in 2010 and 2011. The banded sunflower moth larvae feed on florets and seeds of sunflower, and are relatively common pests in the northern Great Plains (Charlet and Miller, 1993). Damage from the banded sunflower moth has been shown to affect up to $46.5 \%$ of sunflower seeds in a given sunflower head (Charlet et al., 2009). Yield loss in 2011 relative to 2009 ranged from 27 to $33 \%$ across termination treatments, which we hypothesize was related to banded sunflower head moth damage. Yield loss in 2010 relative to 2009 was far more severe (61-75\%), presumably due to the additive effects of banded sunflower moth damage and the severe hail storm before harvest. High populations and damage from the banded sunflower moth in 2 of $3 \mathrm{yr}$ of this study indicate a major pitfall of growing sunflower in the western Corn Belt. This crop will be especially difficult to manage in organic cropping systems, where reactive chemical control options will be limited for the banded sunflower moth.

Soil conservation, quality, and fertility benefits associated with cover crops have been well documented, but increases in crop yield are less commonly reported (Unger and Vigil, 1998; Kuo and Jellum, 2002; Reddy et al., 2003). The lack of yield benefits typically realized following cover crop plantings may be related to previous knowledge gaps regarding the most effective cover crop termination and residue management strategies. However, novel cover crop management systems, like the winter rye-soybean no-till cropping system, have created opportunities for increased crop yield and profitability (Mischler et al., 2010; Davis, 2010). Though unique from the roller-crimper system, results from this study provide support for another effective cover crop management strategy for organic cropping systems. Indeed, termination with the undercutter consistently maintained or increased crop yield relative to disk termination and the more traditional no cover crop organic cropping system. While the utility of the undercutter for cover crop termination and weed management has been previously documented (Creamer et al., 1995; Creamer and Dabney, 2002), this is the first evidence of potential yield benefits associated with a "cover crop-undercutter" organic management system.

\section{Cropping System Profitability}

Throughout the study, crop yield following termination with the undercutter was consistently greater than or equal to yield in the NC and disk treatments, though cover crop treatment did not influence yield in any crop or year of the study. This was a surprising result given that one of the cover crop treatments included a mixture of weeds (WD treatment) managed like a cover crop; thus, results from this study indicate that mixtures of common weed species may provide equivalent cropping system benefits relative to species commonly recognized as cover crops. This result is consistent with one previous study, where corn yield following a winter annual weed cover crop was equal to or greater than yield following a crimson clover cover crop (Sainju and Singh, 2001). Similar to the results of this study, crop yield increase following weed growth occurred despite $<50 \%$ biomass productivity of the weed community relative to cover crop communities (Sainju and Singh, 2001). The concept of "weeds as cover crops" is somewhat unique, but certainly not without precedence. In a related study, Zhu et al. (1991) found that common chickweed (Stellaria media L.; a common weed species) may be a successful cover crop due to its capacity for early maturation, low water use, and ability to reseed itself. Moreover, certain weed species (e.g., quackgrass; Elytrigia repens L.) have high nutritional value and may have utility as a cover crop and subsequent forage companion crop within a diversified crop-livestock rotation (Gift et al., 2008). However, it is important to note that cover crops in this study were not grown to physiological maturity and may not have achieved the full agronomic benefits typically expected of a cover crop (e.g., greater biomass and biological $\mathrm{N}_{2}$ fixation).

The potential utility of weed communities as cover crops becomes increasingly evident after profitability analysis of each cover crop-termination method treatment combination. Indeed, the WD-undercutter treatment combination resulted in the highest net profit for all crops and the entire rotation ( $\$ 1212 \mathrm{ha}^{-1} \mathrm{yr}^{-1}$; Table 4). The "traditional" cover crop mixture-undercutter treatment combinations were also profitable $\left(\$ 1035, \$ 1031, \$ 991\right.$, and $\$ 986 \mathrm{ha}^{-1} \mathrm{yr}^{-1}$ for the 2CC-, 4CC-, 6CC-, and 8CC-undercutter treatment combinations, respectively; Table 4), but less so than the WD treatment because of the added annual costs of cover crop seed, seedbed preparation, and planting (Table 5). Termination with a disk, regardless of cover crop mixtures or weeds, was always less profitable than the traditional no cover crop organic cropping system (Table 4).

Large differences in the profitability of each crop in the rotation are also informative (Table 4). Corn was by far the most profitable crop in all experimental treatments ranging from $\$ 2,225 \mathrm{ha}^{-1} \mathrm{yr}^{-1}$ in the 8CC-disk treatment combination to $\$ 2962 \mathrm{ha}^{-1} \mathrm{yr}^{-1}$ in the WD-undercutter treatment combination. Large economic returns on organic corn are not uncommon (Pimentel et al., 2005), but were especially lucrative in this cropping system due to relatively low input costs (e.g., fewer tillage passes and fertility inputs) and high grain prices (Table 5). Soybean production was only profitable in the undercutter management systems ranging from \$361 to $\$ 587 \mathrm{ha}^{-1} \mathrm{yr}^{-1}$ in the $8 \mathrm{CC}$ - and WD-undercutter treatment combinations, respectively. Average annual profitability of soybean production was limited in this study due to the input costs associated with animal manure in the first year of the study (Table 5). While manure application can improve soil quality and fertility, yield response is typically less consistent in soybean due to the capacity for biological $\mathrm{N}_{2}$ fixation (Schmidt et al., 2001). Sunflower production in this study was only profitable in the WD-undercutter treatment combination $\left(\$ 87 \mathrm{ha}^{-1} \mathrm{yr}^{-1}\right)$, but profits were modest compared to those for corn and soybean (Table 4). Sunflower profitability was limited by incidence of the banded sunflower moth in 2010 and 2011 and also by a relatively low market value for sunflower seed (Table 5). While price premiums for organic sunflower seed may exist in the market, it is often difficult to identify a consistent market value for organic specialty crops (USDA Market News Service, 2012). A guarantee of substantial price premiums would be necessary to make organic sunflower production profitable in the western Corn Belt 


\section{CONCLUSIONS}

Increasing diversity of the cover crop mixture generally increased biomass productivity in 2 of $3 \mathrm{yr}$, highlighting the resilience of diverse cover crop mixtures following management error and severe weather disturbance. Despite differences in productivity, cover crop mixture composition and diversity did not influence soil moisture, soil N, or crop yield. Instead, differences within these factors were driven by termination method. Cover crop mixtures paired with the undercutter for termination did increase yield and profitability compared to a traditional no cover crop organic cropping system (NC control), but undercutter termination of weed mixtures (WD-undercutter treatment combination) proved to be the most profitable cropping system in this study. Although weeds are consistently a top management concern (Walz, 1999; MNDA, 2007), dense weed communities are a common characteristic of organic cropping systems; thus, it may be useful to identify and develop potential uses for these weed communities (Wortman et al., 2010). Given the relative success of the undercutter in both cover cropped and weedy treatments, it may be possible that the "action" of the undercutter in the soil was primarily responsible for the yield benefits observed in this study (e.g., conserving soil moisture and reducing weed seedbank disturbance). Unfortunately, a bare soil-undercutter treatment was not included in this study to elucidate this relationship and the question may require further study.

Results of this study demonstrate the potential for weeds to provide crop yield benefits and farm profitability in excess of that achieved with traditional cover crop species. Despite the short-term yield and economic benefits of the WD-undercutter treatment combination, there are potential pitfalls associated with using weeds as cover crops. For example, if using weeds as a cover crop farmers should take extra caution to prevent weed seed production and replenishment of the seedbank (Davis, 2006). Moreover, many weed species can harbor pests (e.g., soybean cyst nematode[Heterodera glycines]) between cropping seasons (Venkatesh et al., 2000). While yield and economic benefits were observed, substantially lower biomass productivity and spatial heterogeneity of weeds relative to cover crop mixtures will potentially limit the soil conservation benefits typically expected of cover crops.

\section{ACKNOWLEDGMENTS}

The authors wish to acknowledge Tom Galusha for technical support and The Ceres Trust Organic Research Initiative for project funding.

\section{REFERENCES}

Altieri, M. 1999. The ecological role of biodiversity in agroecosystems. Agric. Ecosyst. Environ. 74:19-31. doi:10.1016/S0167-8809(99)00028-6

Ashford, D.L., and D.W. Reeves. 2003. Use of a mechanical roller-crimper as an alternative kill method for cover crops. Am. J. Alternative Agric. 18:37-45. doi:10.1079/AJAA2003037

Barker, D.C., S.Z. Knezevic, A.R. Martin, D.T. Walters, and J.L. Lindquist. 2006. Effect of nitrogen addition on the comparative productivity of corn and velvetleaf (Abutilon theophrasti). Weed Sci. 54:354-363.

Biederbeck, V.O., O.T. Bouman, C.A. Campbell, L.D. Bailey, and G.E. Winkelman. 1996. Nitrogen benefits from four green-manure legumes in dryland cropping systems. Can.J. Plant Sci. 76:307-315. doi:10.4141/cjps96-053

Blevins, R.L., M.S. Smith, G.W. Thomas, and W.W. Frye. 1983. Influence of conservation tillage on soil properties. J. Soil Water Conserv. 38:301-305.

Burket, J.Z., D.D. Hemphill, and R.P. Dick. 1997. Winter cover crops and nitrogen management in sweet corn and broccoli rotations. HortScience 32:664-668.
Caviness, C.C., and J.D. Thomas. 1980. Yield reduction from defoliation of irrigated and non-irrigated soybeans. Agron. J. 72:977-980. doi:10.2134/agronj1980.0 $0021962007200060027 \mathrm{x}$

Charlet, L.D., and J.F. Miller. 1993. Seed production after floret removal from sunflower heads. Agron. J. 85:56-58. doi:10.2134/agronj1993.00021962008500 010012x

Charlet, L.D., G.J. Seiler, J.F. Miller, B.A. Hulke, and J.J. Knodel. 2009. Resistance among cultivated sunflower germplasm to the banded sunflower moth (Lepidoptera:Tortricidae) in the northern Great Plains. Helia 32:1-10. doi:10.2298/HEL0951001C

Chen, C., G. Jackson, K. Neill, D. Wichman, G. Johnson, and D. Johnson. 2005. Determining the feasibility of early seeding canola in the northern Great Plains. Agron. J. 97:1252-1262. doi:10.2134/agronj2005.0004

Clark, A.J., A.M. Decker, and J.J. Meisinger. 1994. Seeding rate and kill date effects on hairy vetch-cereal rye cover crop mixtures for corn production. Agron. J. 86:1065-1070. doi:10.2134/agronj1994.00021962008600060025x

Colla, G., J.P. Mitchell, B.A. Joyce, L.M. Huyet, W.W. Wallender, S.R. Temple et al. 2000. Soil physical properties and tomato yield and quality in alternative cropping systems. Agron. J. 92:924-932. doi:10.2134/agronj2000.925924x

Creamer, N.G., and S.M. Dabney. 2002. Killing cover crops mechanically: Review of recent literature and assessment of research results. Am. J. Alternative Agric. 17:32-40.

Creamer, N.G., B. Plassman, M.A. Bennett, R.K. Wood, B.R. Stinner, and J. Cardina. 1995. A method for mechanically killing cover crops to optimize weed suppression. Am. J. Alternative Agric. 10:157-162. doi:10.1017/ S0889189300006408

Dabney, S.M., J.A. Delgado, and D.W. Reeves. 2001. Using winter cover crops to improve soil and water quality. Commun. Soil Sci. Plant Anal. 32:1221-1250. doi:10.1081/CSS-100104110

Daniel, J.B., A.O. Abaye, M.M. Alley, C.W. Adcock, and J.C. Maitland. 1999. Winter annual cover crops in a Virginia no-till cotton production system: II. Cover crop and tillage effects on soil moisture, cotton yield, and cotton quality.J. Cotton Sci. 3:84-91.

Davis, A.S. 2006. When does it make sense to target the weed seed bank? Weed Sci. 54:558-565. doi:10.1614/WS-05-058R.1

Davis, A.S. 2010. Cover-crop roller-crimper contributes to weed management in notill soybean. Weed Sci. 58:300-309. doi:10.1614/WS-D-09-00040.1

Delate, K., M. Duffy, C. Chase, A. Holste, H. Friedrich, and N. Wantate. 2003. An economic comparison of organic and conventional grain crops in a longterm agroecological research (LTAR) site in Iowa. Am. J. Alternative Agric. 18:59-69. doi:10.1079/AJAA200235

De Vita, P., E. Di Paolo, G. Fecondo, N. Di Fonzo, and M. Pisante. 2007. No-tillage and conventional tillage effects on durum wheat yield, grain quality and soil moisture content in southern Italy. Soil Tillage Res. 92:69-78. doi:10.1016/j. still.2006.01.012

Doak, D.F., D. Bigger, E.K. Harding, M.A. Marvier, R.E. O’Malley, and D. Thomson. 1998. The statistical inevitability of stability-diversity relationships in community ecology. Am. Nat. 151:264-276. doi:10.1086/286117

Ewing, R.P., M.G. Wagger, and H.P. Denton. 1991. Tillage and cover crop management effects on soil water and corn yield. Soil Sci. Soc. Am. J. 55:1081-1085. doi:10.2136/sssaj1991.03615995005500040031x

Gift, N., R.R. Hahn, and J. Mt. Pleasant. 2008. Quackgrass (Elytrigia repens) managed as a cover crop in herbicide-resistant silage corn. Weed Biol. Manage. 8:154-160. doi:10.1111/j.1445-6664.2008.00291.x

Groffman, P.M., P.E. Hendrix, and D.A. Crossley, Jr. 1987. Nitrogen dynamics in conventional and no-tillage agroecosystems with inorganic fertilizer or legume nitrogen inputs. Plant Soil 97:315-332. doi:10.1007/BF02383222

Jose, H.D., and R. Janousek. 2010. 2010 Nebraska farm custom rates. Extension Publ. EC823. Univ. of Nebraska, Lincoln.

Kalinova, J., and J. Moudry. 2003. Evaluation of frost resistance in varieties of common buckwheat (Fagopyrum esculentum Moench). Plant Soil Environ. 49:410-413.

Kornecki, T.S., A.J. Price, R.L. Raper, and A.J. Arriaga. 2009. New roller crimper concepts for mechanical termination of cover crops in conservation agriculture. Renew. Agr. Food Syst. 24:165-173. doi:10.1017/ S1742170509002580

Kuo, S., and E.J. Jellum. 2002. Influence of winter cover crop and residue management on soil nitrogen availability and corn. Agron.J.94:501-508.doi:10.2134/ agronj2002.0501

Kuo, S., and U.M. Sainju. 1998. Nitrogen mineralization and availability of mixed leguminous and non-leguminous cover crop residues in soil. Biol. Fertil. Soils 26:346-355. doi:10.1007/s003740050387 
Leuning, R., A.G. Condon, F.X. Dunin, S. Zegelin, and O.T. Denmead. 1994. Rainfall interception and evaporation from soil below a wheat canopy. Agric. For. Meteorol. 67:221-238. doi:10.1016/0168-1923(94)90004-3

Liebl, R., F.W. Simmons, L.M. Wax, and E.W. Stoller. 1992. Effect of rye (Secale cereale) mulch on weed control and soil moisture in soybean (Glycine max). Weed Technol. 6:838-846.

Lotter, D.W., R. Seidel, and W. Liebhardt. 2003. The performance of organic and conventional cropping systems in an extreme climate year. Am. J. Alternative Agric. 18:146-154. doi:10.1079/AJAA200345

MNDA. 2007. Overview: Experiences and outlook of Minnesota organic farmers. Minnesota Dep. of Agriculture. www.mda.state.mn.us/news/publications/ food/organicgrowing/2007orgsurvresults.pdf (accessed 4 Mar. 2012).

Mirsky, S., W.S. Curran, D.A. Mortensen, M.R. Ryan, and D. Shumway. 2009. Control of cereal rye with a roller/crimper as influenced by cover crop phenology. Agron. J. 101:1589-1596. doi:10.2134/agronj2009.0130

Mischler, R.A., W.S. Curran, S.W. Duiker, and J.A. Hyde. 2010. Use of a rolled-rye cover crop for weed suppression in no-till soybeans. Weed Technol. 24:253261. doi:10.1614/WT-D-09-00004.1

Mulder, C.P.H., A. Jumpponen, P. Hogberg, and K. Huss-Danell. 2002. How plant diversity and legumes affect nitrogen dynamics in experimental grassland communities. Oecologia 133:412-421. doi:10.1007/s00442-002-1043-0

National Sunflower Association. 2012. Sunflower statistics: Historical prices- seed, oil, and meal. Natl. Sunflower Assoc. www.sunflowernsa.com/stats/historicalprices-values/ (accessed 1 Mar. 2012).

North Carolina State University Extension. 2008. Wheat organic production. North Carolina State Univ. Ext. www.ag-econ.ncsu.edu/extension/budgets/ wheat/WHEATorganic.pdf(accessed 1 Mar. 2012).

Parr, M., J.M. Grossman, S.C. Reberg-Horton, C. Brinton, and C. Crozier. 2011. Nitrogen delivery from legume cover crops in no-till organic corn production. Agron. J. 103:1578-1590. doi:10.2134/agronj2011.0007

Pimentel, D., C. Harvey, P. Resosudarmo, K. Sinclair, D. Kurz, M. McNair et al. 1995. Environmental and economic costs of soil erosion and conservation benefits. Science 267:1117-1123. doi:10.1126/science.267.5201.1117

Pimentel, D., P. Hepperly, J. Hanson, D. Douds, and R. Seidel. 2005. Environmental, energetic and economic comparisons of organic and conventional farming systems. Bioscience 55:573-582. doi:10.1641/0006-3568(2005)055[0573:EEA ECO]2.0.CO;2

Pimentel, D., U. Stachow, D.A. Takacs, H.W. Brubaker, A.R. Dumas, J.J. Meaney, J.A.S. O'Neil, D.E. Onsi, and D.B. Corzilius. 1992. Conserving biological diversity in agricultural/forestry systems. Bioscience 42:354-362. doi: $10.2307 / 1311782$

Quemada, M., and M.L. Cabrera. 1995. Carbon and nitrogen mineralized from leaves and stems of four cover crops. Soil Sci. Soc. Am. J. 59:471-477. doi:10.2136/sssaj1995.03615995005900020029x

Reddy, K.N., R.M. Zablotowicz, M.A. Locke, and C.H. Koger. 2003. Cover crop, tillage, and herbicide effects on weeds, soil properties, microbial populations, and soybean yield. Weed Sci. 51:987-994. doi:10.1614/P2002-169

Sainju, U.M., and B.P. Singh. 1997. Winter cover crops for sustainable agricultural systems: Influence on soil properties, water quality, and crop yields. HortScience 32:21-28.

Sainju, U.M., and B.P. Singh. 2001. Tillage, cover crop, and kill planting date effects on corn yield and soil nitrogen. Agron. J. 93:878-886. doi:10.2134/ agronj2001.934878x

Schmidt, J.P., M.A. Schmitt, G.W. Randall, J.A. Lamb, J.H. Orf, and H.T. Gollany. 2001. Soybean varietal response to liquid swine manure application. Agron. J. 93:358-363. doi:10.2134/agronj2001.932358x

Sosnoskie, L.M., C.P. Herms, and J. Cardina. 2006. Weed seedbank composition in a 35-yr-old tillage and rotation experiment. Weed Sci. 54:263-273.

Staver, K.W., and R.B. Brinsfield. 1998. Using cereal grain winter cover crops to reduce groundwater nitrate contamination in the mid-Atlantic Coastal Plain. J. Soil Water Conserv. 53:230-240.
Teasdale, J.R., L.O. Brandsaeter, A. Calegari, and F. Skora Neto. 2007. Cover crops and weed management. In: M.K. Upadhyaya and R.E. Blackshaw, editors, Non-chemical weed management. CAB Int., Wallingford, UK.

Teasdale, J.R., and C.L. Mohler. 1993. Light transmittance, soil temperature, and soil moisture under residue of hairy vetch and rye. Agron. J. 85:673-680. doi:10.2134/agronj1993.00021962008500030029x

Tilman, D. 1996. Biodiversity: Population versus ecosystem stability. Ecology 77:350-363. doi:10.2307/2265614

Tilman, D., C.L. Lehman, and K.T. Thomson. 1997. Plant diversity and ecosystem productivity: Theoretical considerations. Proc. Natl. Acad. Sci. USA 94:18571861. doi:10.1073/pnas.94.5.1857

Tilman, D., P.B. Reich, J. Knops, D. Wedin, T. Mielke, and C. Lehman. 2001. Diversity and productivity in a long-term grassland experiment. Science (Washington, DC) 294:843-845. doi:10.1126/science.1060391

Trenbath, B.R. 1999. Multispecies cropping systems in India: Predictions of their productivity, stability, resilience and ecological sustainability. Agrofor. Syst. 45:81-107. doi:10.1023/A:1006285319817

Unger, P.W., and M.F. Vigil. 1998. Cover crop effects on soil water relationships. J. Soil Water Conserv. 53:200-207.

University of Nebraska-Lincoln Extension. 2011.2011 Cash rental rates up 13-25\%. http://cropwatch.unl.edu/web/cropwatch/archive?articleID $=4499047$ (accessed 1 Mar. 2012).

USDA Market News Service. 2012. Upper Midwest organic grain and feedstuffs report. USDA Market News Serv. www.ams.usda.gov/mnreports/nw_gr113. txt (accessed 1 Mar. 2012).

Venkatesh, R., S.K. Harrison, and R.M. Riedel. 2000. Weed hosts of soybean cyst nematode (Heterodera glycines) in Ohio. Weed Technol. 14:156-160. doi:10.1614/0890-037X(2000)014[0156:WHOSCN]2.0.CO;2

Wagger, M.G. 1989. Cover crop management and nitrogen rate in relation to growth and yield of no-till corn. Agron. J. 81:533-538. doi:10.2134/agronj1989.0002 $1962008100030028 x$

Walz, E. 1999. Third biennial organic farmers survey. Organic Farming Res. Foundation, Santa Cruz, CA.

Ward, R.C. 2011. Ward guide. Ward Laboratories. www.wardlab.com/WardInfo/ WardGuide.pdf (accessed 1 Mar. 2012).

Williams, M.M., II, D.A. Mortensen, and J.W. Doran. 1998. Assessment of weed and crop fitness in cover crop residues for integrated weed management. Weed Sci. 46:595-603.

Wortman, S.E. 2012.Weed biomass, density, and community response to cover crop mixture and mechanical termination method. Chapter 3. Ph.D. diss. Univ. of Nebraska, Lincoln.

Wortman, S.E., A.S. Davis, B. Schutte, and J.L. Lindquist. 2011. Integrating management of soil nitrogen and weeds. Weed Sci. 59:162-170. doi:10.1614/ WS-D-10-00089.1

Wortman, S.E., C.A. Francis, and J.L. Lindquist. 2012. Cover crop mixtures for the western Corn Belt: Opportunities for increased productivity and stability. Agron. J. 104:699-705. doi:10.2134/agronj2011.0422

Wortman, S.E., J.L. Lindquist, M. Haar, and C.A. Francis. 2010. Increased weed diversity, density and aboveground biomass in long-term organic crop rotations. Renew. Agr. Food Syst. 25:281-295. doi:10.1017/S174217051000030X

Wyland, L.J., L.E. Jackson, and K.F. Schulbach. 1995. Soil-plant nitrogen dynamics following incorporation of a mature rye cover crop in a lettuce production system. J. Agric. Sci. 124:17-25. doi:10.1017/S0021859600071203

Zaikin, A.A., D.L. Young, and W.F. Schillinger. 2007. Economic comparison of the undercutter and traditional tillage systems for winter wheat-summer fallow farming. WSU Farm Business Manage. Rep. EB2022E. Washington State Univ. Ext. Serv. http://cru.cahe.wsu.edu/CEPublications/EB2022E/ EB2022E.pdf (accessed 3 Mar. 2012).

Zhu, J.C., C.J. Gantzer, S.H. Anderson, P.R. Beuselinck, and E.E. Alberts. 1991. Water use evaluation of winter cover crops for no-till soybeans. J. Soil Water Conserv. 46:446-449. 